\title{
Dendritic Cell Tumor Cell Lysate Vaccine
}

National Cancer Institute

\section{Source}

National Cancer Institute. Dendritic Cell Tumor Cell Lysate Vaccine. NCI Thesaurus. Code C1988.

A vaccine composed of dendritic cells pulsed with tumor cells lysates that stimulate a potent and specific cell mediated anti-tumor immune response. $(\mathrm{NCl})$ 